\title{
Eight qualities of resilient food systems: Toward a sustainability/resilience index
}

\author{
James Worstell a* \\ Delta Land \& Community \\ John Green b \\ University of Mississippi
}

Submitted July 26, 2016 / Revised October 24 and December 8, 2016, and April 7, 2017 /

Accepted April 7, 2017 / Published online May 17, 2017

Citation: Worstell, J., \& Green, J. (2017). Eight qualities of resilient food systems: Toward a sustainability/resilience index. Journal of Agriculture, Food Systems, and Community Development, 7(3), $23-41$. http://dx.doi.org/10.5304/jafscd.2017.073.001

Copyright (C) 2017 by New Leaf Associates, Inc.

\begin{abstract}
The concept of ecological resilience fills lacunae in sustainability. Solving the world's wicked problems is undermined by the fact that defining sustainability itself is a wicked problem. Traditionally, sustainability is defined by a focus on social, economic, and environmental criteria. In contrast, the ecological resilience perspective on sustainability focuses on continuing adaptation and innovation of complex adaptive systems rather than any evaluation criteria. Prominent among the qualities enabling such resilience is local self-organization. Locally self-organized processing and marketing has long been recognized as a crucial component of sustainable agricultural systems. Ecological resilience research focuses on understanding qualities such as the local self-organization necessary for systems to withstand and overcome disturbances (for example, climate change). This

\footnotetext{
a * Corresponding author: James Worstell, Delta Land \& Community; 920 Highway 153; Almyra, Arkansas 72003 USA; +1-870-673-6346; jim@deltanetwork.org

b Center for Population Studies; 302 Leavell Hall; University of Mississippi; University, Mississippi 38677; +1-662-915-7295; jgreen@,olemiss.edu
}

study seeks to determine the common qualities of such resilient locally organized food systems and compare them with those proposed by the most prominent resilience frameworks in the literature. Our case studies of resilient food systems in recalcitrant areas of the U.S. South result in eight common qualities that are consistent with the most prominent frameworks. This study is part of a long-term effort to define qualities of ecologically resilient systems that are universal across as many scales as possible. Toward that end, this article discusses those eight qualities in order to lay a foundation for future establishment of quantitative indicators and thus form a sustainability/resilience index (SRI). Such a quantitative index enables investigation of the relationships between agricultural system resilience and economic and social demographic indicators.

This article is based on work that was supported by the National Institute of Food and Agriculture, U.S. Department of Agriculture (USDA), through the Southern Region SARE program. USDA is an equal opportunity employer and service provider. Any opinions, findings, conclusions, or recommendations expressed in this publication are those of the authors and do not necessarily reflect the views of the USDA. 


\section{Keywords}

Agroecosystems; Food Systems; Resilience; Sustainability; Self-Organization

\section{Introduction and Literature Review}

For nearly three decades, sustainability has been the goal of people focused on the world's "wicked" problems, including environmental degradation, overpopulation, endangered species, poverty, food insecurity, and climate change (World Bank, 2014). Wicked problems are characterized by interconnected issues and polarized stakeholders with conflicting values, which precludes easy agreement on criteria to determine when a solution is found (Rittel \& Webber, 1973). Achieving consensus around policy incentives to create social change and substitute technologies was assumed by those working in sustainability to eventually lead to a lasting equilibrium between our planet and our social systems (e.g., Forrester, 1971; Curry, 2013). Despite valiant efforts to find sustainable solutions, the world is increasingly out of balance: the wicked problems are becoming more intractable. A revised perspective on sustainability appears needed.

Achieving sustainable agricultural systems has long been a goal internationally (World Commission on Environment and Development, 1987) and in the U.S. (Food, Agriculture, Conservation, and Trade Act 101-624, 16 U.S. C. $\$ 1603,1990)$. However, definitions of sustainable agriculture and sustainability assessment tools focus on whether systems meet a range of other criteria. rather than viewing sustainability as a naturally occurring phenomenon -in contrast to ecological resilience, which is defined as the ability of a system to withstand and overcome disturbance without being destroyed (Holling, 1973). Sustainability assessment tools have been developed for various scales of the food system, including farm, community, ecoregion, and nation (Van Passel \& Meul, 2012). These tools range from indicator sets (Grenz, 2011) to simulation models (e.g. Cerf, Jeuffroy, Prost, \& Meynard, 2012; Van Meensel, Lauwers, Kempen, Dessein, \& Van Huylenbroeck, 2012). All definitions of sustainability seek to move agriculture and food systems toward achieving social, economic, and environmental goals that are agreed on and valued by and defined by particular segments of society. Sustainability as a social movement (Wezel et al., 2009) must maintain focus on these valued societal goals. When focused on such goals, however, defining sustainability itself becomes a wicked problem (Paulson, 2010).

Including societal goals in the definition of sustainability has led to co-optation and antipathy from those who do not share those values. Cooptation of sustainability has been seen with Nestlé, Unilever, Danone's Sustainable Agriculture Initiative Platform (SAIP, 2016), and Monsanto's Global Harvest Initiative (Crossfield, 2009). HoltGiménez and Altieri (2016) have delineated the deep roots of such co-optation. Direct antipathy is shown by the introduction in 26 U.S. state legislatures of legislation opposing sustainable development as proposed in the United Nations Agenda 21 (Frick, Weinzimmer, \& Waddell, 2014). Along with co-optation and antipathy, a recent study indicates "flat-lined public interest in sustainability" since 2004 (Andrew et al., 2016, p. 138). Focusing on understanding the qualities that help systems become resilient appears to be a means of removing sustainability from this wicked situation by defusing political tensions and clarifying the dynamic, systematic nature of human-environment relationships,

Though defining sustainability is fraught with problems, having a legal definition (Food, Agriculture, Conservation, and Trade Act 101-624, 16 U.S. C. $\left.\int 1603,1990\right)$ enabled a systematic attempt, known as the State of the South, in the early 1990s to prioritize sustainable agriculture research and education interventions, which was commissioned by the USDA-supported Southern Sustainable Agriculture Research and Education. Through agroecoregion focus groups, a regional survey, and secondary database analysis, the study concluded that locally owned and organized processing and marketing systems were crucial to develop sustainable agricultural systems (Worstell, 1995). (The study included the first documented "local food systems" workshop, in Williamsburg, Virginia.)

Since the study, encouraging processing and marketing cooperatives, farmers' markets, and community-supported agriculture (CSA) has become extremely popular in much of the United 
States. Several state and federal programs have been implemented to facilitate this effort, including the Value-Added Producer Grant program, the Farmers Market Promotion Program, the Local Foods Promotion Program, the Kentucky Agricultural Development Board, Know Your Farmer, Know Your Food, Food Compass, and many other national, regional, and local programs (Low et al., 2015). The USDA has progressed from dismissing as trivial the likely impact of local foods (USDA, 2001) to trumpeting loudly the importance of local foods (Martinez et al., 2010). The trend toward local food systems is broad and deep. When a conservative Arkansas Congressman says, "The future of food is local" (R. Crawford, personal communication, 2013), Walmart pledges to increase local food to 15 percent of its sales by the end of 2015 (Wenninger, 2013), and it is claimed that every church seems to want its own farmers' market (e.g., C. Sheffield, personal communication, May, 2013), the trend seems ineluctable.

Merely being local, however, does not meet the traditional definition of sustainability (Vermeulen, Campbell, \& Ingram, 2012; Weber \& Matthews, 2008). The State of the South project (Worstell, 1995) concluded that a very specific type of local food system is needed for sustainability, one which is locally organized and locally owned. In the language of ecological resilience, this quality is referred to as self-organization (Holling, 1973). Although all ecologically resilient systems selforganize with the components available locally, we have chosen the term local self-organization (LSO) to underscore the well-established importance for sustainability of processing and marketing that are organized and owned by locally self-organized groups.

The polarization typical of wicked problems can be eliminated when opposing groups build on more basic principles on which they do agree. An ecological resilience approach to sustainability focusing on qualities which enable a system to withstand, adapt, and transform itself in the face of disturbance may be able to reduce polarization while indirectly achieving the goals of the movement. Thus, viewing sustainability from the perspective of ecological resilience may help provide a route out of this wicked problem.

\section{Emergence of Ecological Resilience Perspective on Sustainability}

The concept of ecological resilience emerged from failure to develop stable, sustainable yields in many managed ecosystems, coupled with observations of adaptive cycles that maintain natural ecosystem relationships and functions (Holling, 1973). Resilience first arose as a scientific concept in materials engineering: the "ability of a material to absorb energy when deformed elastically and to return to [the original state] when unloaded" (Total Materia, 2001). Similarly, as developed by Holling, ecological resilience has a specific biological reality: how much disturbance a system can withstand. Resilient systems last; nonresilient systems do not. This definition is widely used, especially in climate change studies (e.g., U.S. CCSP, 2008).

The ecological resilience perspective also differs from many sustainability perspectives in distinguishing resilience from stability. In his seminal resilience paper, Holling (1973) noted that stability is the ability of a system to return to equilibrium after a temporary disturbance. Also called engineering resilience (Holling, 1996), this is the ability of a system to bounce back to its original form, as in materials science. However, societies throughout human history have sought to sustain unsustainable systems (Lowdermilk, 1948). Many societies have striven to eliminate the vagaries of nature and create what today we might call a wellengineered mall (Raskin, 2014). Many "fear that we may be clever enough to create a world that is grievously biologically impoverished, but nevertheless sustainable" (May, 2002, p. 141). Such conceits do not reflect the ecological resilience perspective on sustainability, which emphasizes not so much stability as the ability of the system to absorb change and still persist (Holling, 1996). Resilient systems can fluctuate wildly and change abruptly, to reshape, reform, and adapt themselves.

Explaining and predicting ecological resilience requires understanding the complex adaptive systems people interact with over time. A multitude of frameworks have been developed for these social-ecological systems. However, the complexity of interactions within each socialecological system (SES) make each SES unique and render impossible accounting for every factor 
that conditions resilience now and in the future. Any framework will focus on a few of these factors, as none can encompass all factors (Binder, Hinkel, Bots, \& Pahl-Wostl, 2013).

Seeing the impossibility of predicting interaction within and between innumerable complex adaptive systems, many researchers have focused on defining the basic qualities that appear in all resilient systems. There are both similarities, especially in terminology, and differences between them (listed in Table 1; these are addressed later in relation to the framework proposed in this paper). One of the earliest attempts formulated a set of nine necessary qualities for a resilient world (Walker \& Salt, 2006): diversity, ecological variability, modularity, acknowledgment of slow variables, tight feedbacks, social capital, innovation, overlap in governance, and ecosystem services. Carpenter et al. (2012) clarified the distinction between specific resilience, involving particular disturbances, and general resilience that confers the ability to cope with any disturbance. They posited nine qualities that enable general resilience: diversity, modularity, openness, reserves, feedbacks, nestedness, monitoring, leadership, and trust.

Frankenberger, Mueller, Spangler, and October (2013) built on previous resilience frameworks to include community interactions, in their influential discussion of resilience in the context of international community development. This framework posits seven central "community social dimensions": preparedness, responsiveness/flexibility, learning and innovation, self-organization, diversity, inclusion, and aspirations. The Rockefeller Foundation (2014) expanded resilient systems work to cities. Their City Resilience Framework posits seven qualities of resilient systems: reflective, robust, redundant, flexible, resourceful, inclusive, and integrated. Integrating much of the previous work on resilience frameworks, the most wellknown center for study of ecological resilience, the Stockholm Resilience Center (2015), developed a set of "seven principles that are considered crucial for building resilience in social-ecological systems": maintain diversity and redundancy, manage connectivity, manage slow variables and feedbacks, foster complex adaptive systems, encourage learn- ing, broaden participation, and promote polycentric governance.

Specific to agroecosystems is the framework developed by Cabell and Oelofse (2012), who describe 13 categories of indicators shown to be associated with resilience: social self-organization, ecological self-regulation, appropriate connectedness, functional and responsive diversity, optimal redundancy, reflective and shared learning, spatial and temporal heterogeneity, exposure to disturbance, coupling with local natural capital, global autonomy and local interdependence, honoring of legacy, building human capital, and being reasonably profitable.

In contrast to these ecological resilience frameworks, some conceptualizations of resilience include external assistance to assist systems in becoming resilient. These approaches to resilience include those developed by the UN Food and Agriculture Organization (FAO) and the University of Florence (e.g., Alinovi, Mane, \& Romano, 2009; Alinovi, D’Errico, Mane, \& Romano, 2010; Ciani \& Romano, 2013; FAO, 2014), Oxfam (Hughes \& Bushell, 2013), and the Livelihood Vulnerability Index (e.g., Hahn, Riederer, \& Foster, 2009). The Alinovi-FAO effort has produced a household resilience index, which posits that resilience is a function of "IFA=income and food access; $\mathrm{ABS}=$ access to basic services; $\mathrm{AA}=$ agricultural assets; $\mathrm{NAA}=$ non-agricultural assets; $\mathrm{APT}=$ agricultural practice and technology; $\mathrm{SSN}=$ social safety nets; $\mathrm{CC}=$ climate change; $\mathrm{EIE}=$ enabling institutional environment; $\mathrm{S}=$ sensitivity; $\mathrm{AC}=$ adaptive capacity" (FAO, 2014, p. 4). Oxfam (Hughes \& Bushell, 2013) maintains that resilience is the weighted sum of five factors: livelihood viability, innovation potential, contingency resources and support access, integrity of natural and built environments, and social and institutional capacity. The Livelihood Vulnerability Index (Hahn et al., 2009) is composed of seven factors: socio-demographic profile, livelihood strategies, social networks, health, food, water, and natural disaster and climate variability.

Many parameters in these three indices are consistent with those of ecological resilience frameworks. The admirable goal of the FAO, 
Oxfam, and Livelihood Vulnerability indices, however, is to assist aid agencies in helping households survive with a combination of external assistance and modification of household qualities. Thus, if resilience is a measure of ability to withstand disruption external to the system, and aid agency assistance programs are part of the system, then the indices do not measure resilience at the household level, but at the scale of the aid agencies assisting the households. Resilience at the household or community level, however, would incorporate the ability to withstand fluctuations in aid agency policies, along with disruptions from policy, market, input supply, and other systems beyond the household or community level. As Levine (2014) discusses at length, resilience indices that incorporate measures at various scales can only estimate resilience at the highest scale each addresses.

Since the ecological resilience approach focuses on defining the qualities that are necessary for systems to achieve general resilience, resilience must be measured at specific scales for specific types of systems. Resilience at the household scale, community scale, and aid agency scale can even be contradictory (Levine, 2014). This is apparent when we look at a crucial component of resilience: self-organization.

\section{Local Self-organization (LSO) Is Necessary But} Not Sufficient for Resilience To Emerge

Self-organization refers to the emergence of new structures and systems from systems already present in a locality (Camazine et al., 2003). An aid agency organizing a community and its households for resilience can be considered self-organized at the scale of the aid agency, but not at the scale of the household. Systems highly influenced by external organizations are at least somewhat dependent on those entities. All prominent frameworks of ecological resilience contend that self-organization is one of the necessary qualities of any resilient system.

In some regions, systems of LSO processing and marketing of food survive and thrive; in others they do not. The Southern U.S. is a region that generally ranks low in LSO and in local food system activities more broadly. One prominent 2016 index (Strolling of the Heifers, 2016) puts only Virginia of all Southern states in the top half of states in presence of local food systems. South Carolina is 27th, North Carolina 34th, and the other ten Southern states are ranked in the lowest 13 states. Except for the top four Southern states (Virginia, North Carolina, South Carolina and Kentucky), all others have been declining in rankings in each of the last three years. Yet in each of the lowest ranked states, some LSO food systems have proven resilient. Study of the food systems that have survived and thrived in recalcitrant areas should provide insight into the qualities of resilient systems beyond LSO.

This study seeks to determine the common qualities of such resilient LSO food systems and compare them with those proposed by the most prominent resilience frameworks. Obtaining a defined set of qualities of resilient Southern systems lays the foundation for exploration of indicators for each of these qualities. Combining scores on indicators across all the qualities could then result in a sustainability/resilience index, which can be correlated with social demographic characteristics such as poverty, health, and education. Then it will be possible to determine the extent to which levels of sustainability/resilience are associated with the societal goals often measured by sustainability assessments. The work described here has accomplished the first step by identifying the common qualities of resilient food systems.

\section{Applied Research Methods}

The lead author for this article led a team to conduct case studies. We used standard case recruitment and selection methods (Lauckner, Paterson, \& Krupa, 2012) to choose the subjects for our case studies. In addition to being from one of the three states with few LSO processing and marketing systems (AR, TN, and MS), but similar geographically and demographically to states with many such systems (VA, NC, KY, SC), the primary selection criteria were that the system must be attempting to integrate ecologically sound production, processing, and marketing; must have lasted for a minimum of five years; must have originated and be located in an area where few such systems have developed; and key managers involved in the system had to demonstrate willingness to 
participate in all aspects of the study. A multiple case study design was chosen in order to study our topic from several perspectives and contexts (Yin, 2014). We examined systems where agricultural system managers worked independently in different contexts and communities, providing the opportunity to identify common and distinct processes. Such resilient systems proved difficult to find, but through our extensive contacts in the region, especially Southern Sustainable Agriculture Working Group, we found three systems in each state, nine in total, that fulfilled our criteria.

The case study protocol outlined the key information to be gathered from each case and primary sources (Yin, 2014). Initial issues for exploration were extrapolated from project leader experience, previous ecological resilience research, and related literature. These initial issues were points of departure to guide interview questions and preliminary analysis. The initial researcheridentified issues were influenced by issues raised by study participants. Particular issues were developed and explored in each case to guide data collection and analysis for the individual case descriptions. The emerging issues from each case were then examined to identify shared issues, which then directed the cross-case analysis. Regularly revisiting and refining these issues during data collection and preliminary analysis provided an emergent theoretical structure from the data collection processes.

As is consistent with case study design, data collection methods in this study included in-depth semi-structured interviews, document review, direct observation, and participant observation. At least four interviews of key system managers were conducted for each case study. Forty-three interviews in total were conducted for the nine case studies. Each interview was written up as a vignette for later analysis. The vignettes and related information were then integrated to create each of the case studies. Information was gathered from the inception of the initiative to the time of data collection, to capture process changes.

Data analysis occurred in three stages. Stage 1 involved the independent, in-depth analysis of each case. The major determinants of resilience in each case were identified through consensus by the three interviewers who participated in each case study interview. Stage 2 involved a cross-case analysis of the nine cases. In Stage 2, each case's main processes were compared to explore how different contexts and processes varied across the cases. The key qualities that were identified for each case as described previously were re-examined to distill common qualities that were addressed differently across the nine cases. Finally, casespecific qualities were identified that were present in all cases. In Stage 3, conclusions from the case studies were compared to each of the six prominent resilience frameworks discussed above.

\section{Results and Theory Elaboration}

Nine case studies of resilient food systems in Tennessee, Arkansas, and Mississippi were developed and analyzed in the context of the frameworks noted above, resulting in a theoretical framework applicable to all cases. The case studies are available on our resilience website (Worstell, 2016). They describe:

1. An Arkansas system uniting Ozark farms through online marketing and cooperative processing.

2. An Arkansas family of a father and two sons with independent direct marketing ventures through farmers markets and permanent storefronts.

3. An Arkansas social organization uniting farmers, restaurants, and wholesale markets.

4. A Tennessee college and associated farmers and food hub.

5. A Tennessee system of farmers, restaurants, a foundation, and a butchery.

6. A Tennessee biodynamic grower network with a CSA and restaurants.

7. A Mississippi system of three competitive markets and their growers.

8. A Mississippi cooperative and its growers and market.

9. A Mississippi association of farmers conducting joint marketing.

Eight qualities were found to be common to to all nine case studies and consistent with the qualities identified by the most prominent resilience frameworks. These eight qualities are compared to the six frameworks in Table 1. We 
Table 1. Comparison of the Eight Qualities of Resilient Systems in Six Prominent Frameworks for Analysis of Resilient Systems

\begin{tabular}{|c|c|c|c|c|c|c|}
\hline & $\begin{array}{l}\text { Cabell \& Oelofse } \\
(2012)\end{array}$ & $\begin{array}{l}\text { Carpenter et al. } \\
\text { (2012) }\end{array}$ & $\begin{array}{l}\text { Rockefeller } \\
\text { Foundation (2014) }\end{array}$ & $\begin{array}{l}\text { Stockholm Resilience } \\
\text { Center (2015) }\end{array}$ & $\begin{array}{l}\text { Frankenberger et al. } \\
\text { (2013) }\end{array}$ & Walker \& Salt (2006) \\
\hline 1. Modular connectivity & $\begin{array}{l}\text { Appropriately } \\
\text { connected }\end{array}$ & $\begin{array}{l}\text { Modularity, } \\
\text { openness, } \\
\text { feedbacks, monitor- } \\
\text { ing, leadership, and } \\
\text { trust }\end{array}$ & $\begin{array}{l}\text { Integrated (con- } \\
\text { nected), robust } \\
\text { (modularity) }\end{array}$ & $\begin{array}{l}\text { Manage connectivity, } \\
\text { manage slow vari- } \\
\text { ables and feedbacks }\end{array}$ & Social capital & $\begin{array}{l}\text { Modularity, tight } \\
\text { feedbacks, social } \\
\text { capital }\end{array}$ \\
\hline 2. Locally self-organized & $\begin{array}{l}\text { Socially self-organized; } \\
\text { globally autonomous } \\
\text { and locally inter- } \\
\text { dependent }\end{array}$ & Nestedness & Inclusive & $\begin{array}{l}\text { Promote polycentric } \\
\text { governance systems } \\
\text { (nestedness) }\end{array}$ & $\begin{array}{l}\text { Self-organized, } \\
\text { inclusive }\end{array}$ & $\begin{array}{l}\text { Overlap in } \\
\text { governance }\end{array}$ \\
\hline $\begin{array}{l}\text { 3. Increasing physical } \\
\text { infrastructure }\end{array}$ & & & Robust & & $\begin{array}{l}\text { Community assets, } \\
\text { preparedness, } \\
\text { aspirations }\end{array}$ & \\
\hline $\begin{array}{l}\text { 4. Responsive redun- } \\
\text { dancy/Back-ups }\end{array}$ & Optimally redundant & Reserves & Redundant & Maintain redundancy & & \\
\hline $\begin{array}{l}\text { 5. Complementary } \\
\text { diversity }\end{array}$ & $\begin{array}{l}\text { Functional and } \\
\text { responsive diversity; } \\
\text { spatial and temporal } \\
\text { heterogeneity }\end{array}$ & Diversity & & Maintain diversity & Diversity & Diversity \\
\hline $\begin{array}{l}\text { 6. Conservative } \\
\text { innovation }\end{array}$ & $\begin{array}{l}\text { Builds human capital, } \\
\text { honors legacy, } \\
\text { reflected and shared } \\
\text { learning }\end{array}$ & Openness & $\begin{array}{l}\text { Reflective, flexible, } \\
\text { resourceful }\end{array}$ & Encourage learning & $\begin{array}{l}\text { Learning and innova- } \\
\text { tion; responsiveness/ } \\
\text { flexibility, memory }\end{array}$ & Innovation \\
\hline $\begin{array}{l}\text { 7. Ecologically self- } \\
\text { regulated (works with } \\
\text { nature) }\end{array}$ & $\begin{array}{l}\text { Ecologically self- } \\
\text { regulated, coupled } \\
\text { with local natural } \\
\text { capital }\end{array}$ & & Integrated & & & $\begin{array}{l}\text { Ecological variability, } \\
\text { ecosystem services }\end{array}$ \\
\hline $\begin{array}{l}\text { 8. Embracing } \\
\text { disturbance for } \\
\text { transformation }\end{array}$ & $\begin{array}{l}\text { Exposed to disturb- } \\
\text { ance, temporal } \\
\text { heterogeneity }\end{array}$ & & Reflective & $\begin{array}{l}\text { Foster complex } \\
\text { adaptive systems } \\
\text { thinking }\end{array}$ & Responsiveness & \\
\hline
\end{tabular}

describe these qualities with examples from the case studies and from other resilience frameworks.

Locally Self-organized (LSO)

The case studies were chosen because they were locally self- organized food systems, which we define as food systems where farmers, marketers, and processors in one agroecoregion have developed a system owned and managed by those same farmers, marketers, and processors. The systems studied ranged from farmersrestaurants-butchers-philanthropists in Southeast Tennessee to 
farmers-meat processors-aggregators-food store operators in north central Arkansas.

Ecosystems unmanaged by man are finely attuned to local conditions; farms and food systems often are not. Frankenberger et al. (2013) and Cabell and Oelofse (2012) have an especially strong focus on the LSO quality. Cabell and Oelofse (2012) use the term socially self-organized, and specifically cite the example of community supported agriculture (CSA) systems and farmers' markets. They make a distinction echoed in many other frameworks, that LSO networks can be more responsive and adaptable to changing conditions than can larger groups. Top-down initiatives can fail if the timing is wrong, if the needs are misinterpreted, or if there is no buy-in from stakeholders. Frankenberger et al. (2013) and Rockefeller Foundation (2014) refer to "buy-in from stakeholders" as inclusiveness.

Other frameworks are less specific about the need for LSO, but imply its importance in the qualities labeled overlap in governance (Walker \& Salt, 2006), nestedness (Carpenter et al., 2012), and polycentric governance (Stockholm Resilience Center, 2015). These three frameworks emphasize need for governance above the farm and community level to be focused on resilience. Since, as we discussed earlier, resilience indices that include measures at higher scales can only measure at the highest scale where indicators are measured, regional, national, and world governance must be examined at their own scales. All ecosystems are nested, since every system is composed of systems. Every resilient system contributes to the resilience of subsystems of which it is composed. Those subsystems are resources or assets for the larger system that must be enhanced and maintained, as addressed with the next resilience quality.

\section{Responsive Redundancy or Back-ups}

Resilient systems have back-ups and replenish their components. Ecologists use the term redundancy to mean that several of each component of a system are present and they are replaced when lost. (This should not be confused with uses of the term in other fields, such as labor redundancy or redundancy in grammar.) Redundancy that promotes resilience is responsive to needs of the system. The resilient system has mechanisms to control excessive fecundity. Skills, abilities, and functions are also reproduced and passed on to the next generation to insure that that generation survives and multiplies.

All the resilient case study farmers and entrepreneurs had family and friends who were deeply involved in the system and able to take over functions as needed. One Arkansas system is a fivegeneration family farm where the two most recent generations have maintained and expanded a LSO food production and marketing system in existence for more than 25 years. A Mississippi system showed high levels of redundancy when members of the group continued farm and market operations when the husband and wife managers were absent for months with a sick child. A farm in one of the Tennessee case study systems is transitioning its enterprise to an employee and the founders' children.

Redundancy, the ability of a system to replace as needed its components, is seen as crucial in all resilience frameworks, though Frankenberger et al. (2013) does not explicitly use the term. Their term, reserves, as noted above, has a similar definition as redundancy in our framework. Cabell and Oelofse (2012) use the term "optimally redundant," which highlights the crucial qualification that redundancy inevitably increases inefficiency of the system.

\section{Accumulating Reserves and Physical Infrastructure}

As they developed, all our case studies systems saw an increase in physical infrastructure, including natural capital, human-made environmental capital, and technological capital as defined by Stokols, Lejano, and Hipp (2013). Managers in these systems delayed consumption and profit-taking to build infrastructure and reserves. This quality is reflected in such indicators as increasing water harvesting capability, increasing soil organic matter, making trees and permanent pastures part of the production system, increase on-farm storage, and increasing value-added processing capacity. Every farm in all nine case studies reported gradually increasing soil quality, water harvesting capacity, and on-farm storage. Six of the nine showed increases in on-farm processing infrastructure.

The Rockefeller Foundation (2014) is most 
explicit of all the frameworks about the need for physical infrastructure. They use the term "robust" to describe well-conceived, constructed, and managed physical assets, which enable a system to withstand the impacts of hazard events without significant damage or loss of function. Cabell and Oelofse (2012) emphasize that resilient systems are coupled with local natural capital — the slow variables such as soil organic matter, hydrological cycles, and biodiversity. The Stockholm Resilience Center (2015) also notes the importance of managing slow variables, though without emphasis on building up such infrastructure, perhaps because their focus is not primarily agroecosystems.

Frankenberger et al. (2013) are explicit about the necessity of building infrastructure for resilient systems. In other frameworks, this quality seems to be assumed in such terms as reserves (e.g., Carpenter et al., 2012) that contribute to recovery from disturbance. Reserves cannot be established without the productive infrastructure needed to create them. Frankenberger et al. (2013) highlight community assets, which are resources that enable communities to meet the basic needs of their members and reduce vulnerability to shocks. However, the broad definition of assets-including both tangible and intangible assets, involving social, human, financial, natural, physical, and political capital-makes measurement of this quality difficult in their framework (Frankenberger et al., 2013). They propose two other qualities that are not explicitly stated in other conceptualizations, but are related to increasing assets or infrastructure: preparedness and aspiration. Preparedness refers to the community resources needed to cope with disturbance. Aspirations are the underlying personal traits that induce people to make investments needed to cope with disturbance. Most clearly of the frameworks, Frankenberger et al. (2013) point out that actors in resilient social agroecosystems display an ability to delay gratification and a desire to create infrastructure to accumulate reserves.

\section{Modular Connectivity}

In all case studies the farmers and entrepreneurs were independent, but highly connected to many other farmers, marketers, and suppliers. Sensitivity and responsiveness to feedback of other systems does not, however, undermine modularity in resilient systems. High levels of connectivity mean resilient systems are sensitive and responsive to feedback, though in a modular fashion. Modular subsystems have enough independence that damage or failure of even a key sub-system has low probability of generating failure throughout the system. Such subsystems could be a farm in a network of connected farms or an individual enterprise on one farm, depending on the scale at which resilience is examined. Yet each component of the system is connected enough to detect and respond to changes throughout the system. Resilient connectivity has a few strong connections and many weak connections. Successful individual businesses only lead to resilient development when they are part of a collaborative network of businesses and organizations.

All case study systems were connected to an abundance of marketing and production sources, while not being solely dependent on any one of these connections. One Mississippi system was a 40-year-old cooperative of almost 100 members that is part of state and national collaborations of cooperatives. Another Mississippi system features a nonprofit that facilitates connections between thousands of farmers, marketers, processors, and policy experts. One Arkansas case study system has farmers, marketers, processors, and aggregators among its over 500 members.

All prominent frameworks for resilience recognize the importance of connectivity and modularity. Some who are mainly concerned with human systems make social capital a separate category. While recognizing the vital important of social capital in the Community Capitals Framework (Flora, Flora, \& Gasteyer, 2015) and the Sustainable Livelihoods Framework (e.g., Scoones, 1998), social capital can be seen as a subset of the connectivity which occurs in all systems, not just human systems.

Carpenter et al. (2012) have a strong focus on modular connectivity, but they split this quality into several separate areas: modularity, managing feedback, monitoring, openness, and development of trust. Cabell and Oelofse (2012) call the quality "appropriately connected." They extol connectivity, but do not address situations where high 
connectivity leads to low resilience to disturbance. If components of the system are not modular or independent, it cannot be resilient when disturbance floods though systems. Frankenberger et al. (2013) see the vital importance of social capital, but discuss other aspects of connectivity in less detail, and do not discuss modularity. The Rockefeller Foundation (2014) uses slightly different terminology. Instead of connectivity, they refer to resilient systems as integrated, when exchange of information between systems enables them to function collectively and respond rapidly through shorter feedback loops. Instead of modularity, they use the term robust to refer to well-designed systems that actively avoid over-reliance on a single asset, cascading failure, and design thresholds that might lead to catastrophic collapse. The Stockholm Resilience Center (2015) focuses on managing connectivity and feedbacks, but with less emphasis on modularity than other frameworks.

\section{Complementary Diversity}

The peculiar diversity of resilient systems is complementary in function. For example, resilient systems are composed of diverse complementary systems that turn wastes of one system into valuable inputs to other system. Complementary diversity is characterized by a variety of crops, markets, sources of inputs, and spatial heterogeneity. Heterogeneity of features within the landscape and on the farm-diversity of inputs, outputs, income sources, markets, pest controls-all reflect this diversity in resilient systems. One Mississippi system included dozens of farmers marketing together with complementary products. Collaborating with multiple suppliers, marketing outlets, and fellow farmers to encourage symbiosis and mutualism is evident in all the case studies.

All resilient food system case study farmers and entrepreneurs had a diversity of enterprises. One Tennessee system combined a dairy and fruit and vegetable operations with sales to farmers markets and restaurants, and direct to consumers. One farm in an Arkansas case study system included dozens of crops grown nowhere else in Arkansas. The diversity of the case studies was characterized by complementarity. While diverse, each enterprise was complementary to other enterprises. The managers recognized that lack of complementarity could compromise resilience.

Diversity is extolled by nearly all resilience frameworks. Some frameworks-e.g., Carpenter et al. (2012), Stockholm Resilience Center (2015), and Frankenberger et al. (2013) — do not address the need for diversity to be complementary or the fact that diversity can undermine resilience if, for example, enterprises compete for time and resources. Cabell and Oelofse (2012), in contrast, make this distinction explicit. They also include, as a separate quality, spatial and temporal heterogeneity; that is, lack of uniformity across the landscape and through time. We see this as a measure of diversity, and not a separate quality from diversity.

\section{Ecological Integration (Working with Nature)}

The diverse managed components of resilient systems are complementary not just to each other, but to unmanaged ecosystem services. Ecological integration means using natural ecological processes to increase productivity and decrease imported inputs. Basic examples include reduced tillage, integrated pest management, and use of cover crops-practices many farmers have embraced. This aspect of resilience places a value on the preservation of minimally managed or uncultivated land, left to the natural cycles of insects, birds, and other beneficial organisms. Farms that maintain plant cover and incorporate more perennials provide habitat for predators and parasitoids, use ecosystem engineers such as soil fauna, and align production with local ecological parameters are naturally more resilient than farms that stress the use of increasing amounts of chemical fertilizers and pesticides, excluding nature as much as possible for the sake of monocultures. Rotational grazing to build soils, inoculating soils with beneficial microorganisms, and various agroforestry practices are more advanced methods of ecological integration. Permaculture is an applied example of ecological integration in resilient systems, as we have discussed elsewhere (Worstell \& Johnson, 2015).

The myriad studies on ecological integration are summarized in our online book that gives a plethora of practical tips for increasing that quality of resilience (Worstell \& Johnson, 2016). Each 
farmer in our case studies has found ways of using local ecological systems to increase productivity, whether through biodynamic farming (the Central Tennessee case study) or organic methods (the Central Arkansas study), rotational grazing (case studies in all three states), or integrated pest management (case studies in all three states).

Of the most prominent resilience frameworks, Cabell and Oelofse (2012) are the most explicit in recognizing the value of ecological integration, stating that the more intact and robust the regulating ecosystem services are, the more resilient the agroecosystem. They further suggest that more resilient systems are more capable of self-regulation. The Rockefeller Foundation's discussion of integration (2014) and the importance placed on diversity by other frameworks make this quality implicit in all the frameworks. Our analysis of LSO food systems indicates that the quality should be explicitly measured and induced.

\section{Conservative Innovation and Flexibility}

Resilient systems are open to new ideas-innovation-while retaining ideas that work from the past. Practical learning is valued, as are elders and heirloom seed varieties. Moore, McCarthy, Byrne, and Ward (2014) call this quality reflexive resilience. Innovation also applies to the whole system where it is manifested in the transformation quality discussed below.

Since resilience requires the ability to come up with uniquely appropriate responses in diverse situations, a system needs a variety of approaches. Ecologically resilient systems stress multiple, overlapping strategies rather than single solutions. Collaboration between universities, research centers, and farmers, and cooperation and knowledge sharing between farmers reflect the quality of flexibility in resilient systems.

All case study systems were highly innovative, but in a very conservative fashion. All their innovations fit their existing systems and maintained successful traditions. An Arkansas farmer in one case study manages both his organic farm and a conventional farm that is gradually incorporating innovative organic methods. All case studies were innovative for their area, but had chosen innovations that were working successfully in similar regions in other parts of the world. For example, one case study system in Arkansas has introduced various crops grown only in similar microclimates in California and China, for discerning local customers.

Innovation is a necessary quality of resilient systems in nearly all frameworks. Carpenter et al. (2012) discuss it under their term openness; the Rockefeller Foundation (2014) under the quality "flexible, resourceful, reflective"; Cabell and Oelofse (2012) under the quality "build human capital and reflected and shared learning"; Stockholm Resilience Center (2015) under the quality "encourage learning"; Frankenberger et al. (2013) under the quality "responsiveness/ flexibility and learning and innovation." Many frameworks, however, are not as explicit about the dangers of innovation that do not honor legacy, as Cabell and Oelofse (2012) put it. Legacy is the memory component of a SES. Frankenberger et al. (2013) refers to this quality as a strong community memory of traditions, practices, past disasters, and changing conditions which supports a community's abilities to draw on experience to prepare for and respond to similar challenges.

\section{Periodic Transformation: Reorganizing, Reforming, Embracing Disturbance}

Resilient systems are continually reforming themselves. In a SES, this is reflected in regular turnover of leadership, lack of authoritarian leaders, inheritance taxation, and mandatory retirement. Reformation is intimately related to self-organization and innovation. Innovation at one scale is transformation at another scale.

The resilient food systems in our case studies all had undergone regular transformations and sought out means of transforming their systems. One Arkansas system moved from traditional cotton production, to a farmers market and agritourism center, to inclusion of a restaurant and grocery stores, and then to direct marketing of highly diverse crops including organic production. A Tennessee system changed from direct marketing fruits and vegetables, to sales to restaurants, to a U-pick operation coupled with a cheese dairy.

Of the prominent resilience frameworks, Cabell and Oelofse (2012) most explicitly state that 
exposure to disturbance is a quality of resilient systems. Their indicator of temporal heterogeneity also recognizes the transformation over time of resilient systems. Frankenberger et al. (2013) notes the importance of transformative capacity.

Though innovation within a system is transformative on a smaller scale and is a quality all recognize as necessary to resilience, most frameworks do not make the leap to recognizing that sometimes the innovation required might be so extensive as to transform the entire system. This limited embrace of transformation is illustrated by the Rockefeller Foundation (2014) emphasis on reflective systems, which notes that resilient systems have mechanisms to continuously evolve, but does not go so far as to say that periodically they are totally transformed. Our work with LSO food systems indicates that transformation is a quality necessary to resilience and must be explicitly included.

\section{Qualities That Do Not Distinguish Resilient from Nonresilient Systems}

Nearly all the factors deemed necessary by other frameworks are incorporated in the eight qualities of resilience found consistently in LSO food systems. Two are not, however. The Stockholm Resilience Center is the only framework that includes the quality of "fostering" complex adaptive systems (CAS). A CAS does embrace and use disturbance for transformation. As all living systems are complex adaptive systems (Levin, 1998), however, fostering a CAS does not distinguish a resilient from a nonresilient system. Similarly, "sufficient profit," one of the 13 indicator categories of Cabell and Oelofse (2012), is not a quality that distinguishes between resilient and nonresilient systems. A resilient system will be generating sufficient profit, but profit is not necessarily an output that leads to resilience. Excess profit can certainly lead to nonresilience if it is extracted by undermining system qualities that promote resilience. Other systems may not be profitable for several years due to expenses related to increasing resilience. Resilient systems, by definition, withstand economic disturbances and shocks due to the qualities inherent in the system. However, using resilience to economic disturbances as a defining characteristic of resilience makes the definition circular.
Which Set of Qualities Is the Most Useful?

Each of the eight qualities we present appears to be necessary for resilience in our case studies of resilient food systems in recalcitrant Southern states. Those who arrived at the other sets of qualities likely feel that their set fits the systems they know best. The best way to decide between the frameworks would be to attempt to induce resilience in a particular system following the predictions of each framework. This requires operationalizing these concepts, that is, defining specific ways of inducing and measuring each of the qualities espoused by each framework.

In Table 2 we have generated activities and measures at various scales which could be used to test whether the eight qualities we identified in studies of resilient food systems improve resilience and sustainability, and whether each is necessary and whether together they are sufficient to induce resilience in systems at various scales. If those espousing alternative frameworks attempt to operationalize their concepts as well, then alternative models can be tested to see which predicts resilience most fully. The goal of this table is to stimulate those interested in an ecological resilience perspective on sustainability to examine agricultural systems at various scales to determine what qualities lead to systems which survive and thrive in response to disturbance, as well as to generate measurable indicators of these qualities.

\section{Combining the Eight Qualities into an Overall Index of Sustainability/Resilience}

Operationalizing the qualities of resilience such that they can be quantified lays the foundation for creating an overall index of sustainability/resilience. If such an index is a good predictor of resilience, it would help managers of a systemfarm, community, food system, etc.-improve resilience and be able to track changes in resilience. Indicators of the qualities of resilience are publicly available at the county level in databases such as National Census of Agriculture, Decennial Census, American Community Survey Five-Year Estimates, Net Migration Patterns for U.S. Counties, County Health Rankings, USDA Food Atlas, and USDA Farm to School Database. Aggregate county-level data from these sources could be used to test the 


\begin{tabular}{|c|c|c|c|c|c|c|c|c|}
\hline & $\begin{array}{l}\text { Modular } \\
\text { connectivity }\end{array}$ & $\begin{array}{l}\text { Local self- } \\
\text { organization }\end{array}$ & $\begin{array}{l}\text { Infrastructure } \\
\text { (e.g., soil, water, } \\
\text { increasing) }\end{array}$ & $\begin{array}{l}\text { Responsive } \\
\text { redundancy }\end{array}$ & $\begin{array}{c}\text { Complementary } \\
\text { diversity }\end{array}$ & $\begin{array}{c}\text { Conservative } \\
\text { innovation }\end{array}$ & $\begin{array}{l}\text { Integration of } \\
\text { natural eco- } \\
\text { logical systems }\end{array}$ & $\begin{array}{c}\text { Periodic } \\
\text { transformation }\end{array}$ \\
\hline $\begin{array}{l}\text { Federal } \\
\text { policy } \\
\text { system }\end{array}$ & $\begin{array}{l}\text { Cooperative } \\
\text { development } \\
\text { programs } \\
(\mathrm{RCDG})^{\mathrm{a}}\end{array}$ & $\begin{array}{l}\text { VAPG, FMPP, } \\
\text { LFPP, F2S imple- } \\
\text { mented with } \\
\text { planning funds } \\
\text { for local projects }\end{array}$ & $\begin{array}{l}\text { NRCS support for } \\
\text { increasing assets } \\
\text { (soil, water catch } \\
\text { and conserve, } \\
\text { equipment, } \\
\text { fence) }\end{array}$ & $\begin{array}{l}\text { BFRDP focused } \\
\text { on training a new } \\
\text { generation of } \\
\text { farmers }\end{array}$ & $\begin{array}{l}\text { Opportunity } \\
\text { workshops to } \\
\text { encourage } \\
\text { diversification of } \\
\text { crops and } \\
\text { markets }\end{array}$ & $\begin{array}{l}\text { On-farm innova- } \\
\text { tion trials of tools } \\
\text { incorporating } \\
\text { traditional } \\
\text { methods, tools } \\
\text { and products }\end{array}$ & $\begin{array}{l}\text { Workshops to } \\
\text { increase use of } \\
\text { ecological ser- } \\
\text { vices (beneficial } \\
\text { uses, cover } \\
\text { crops, MIG) }\end{array}$ & $\begin{array}{l}\text { Support for new } \\
\text { leader training in } \\
\text { farm and coop- } \\
\text { erative groups }\end{array}$ \\
\hline Community & $\begin{array}{l}\text { Facilitates } \\
\text { communication } \\
\text { between all } \\
\text { members }\end{array}$ & $\begin{array}{l}\text { Local firms } \\
\text { encouraged, } \\
\text { outsiders must } \\
\text { partner }\end{array}$ & $\begin{array}{l}\text { Increasing infra- } \\
\text { structure for } \\
\text { services }\end{array}$ & $\begin{array}{l}\text { Community } \\
\text { maintains and } \\
\text { replaces all } \\
\text { needed services }\end{array}$ & $\begin{array}{l}\text { Increased diver- } \\
\text { sity dedicated to } \\
\text { local heritage }\end{array}$ & $\begin{array}{l}\text { Community em- } \\
\text { braces innovation } \\
\text { and new practices } \\
\text { as preserves } \\
\text { heritage }\end{array}$ & $\begin{array}{l}\text { Increasing area } \\
\text { of parks and } \\
\text { woodlands }\end{array}$ & $\begin{array}{l}\text { New and young } \\
\text { leaders } \\
\text { encouraged }\end{array}$ \\
\hline $\begin{array}{l}\text { Group of } \\
\text { farmers }\end{array}$ & $\begin{array}{l}\text { Farmers trust } \\
\text { and value other } \\
\text { members of } \\
\text { group }\end{array}$ & $\begin{array}{l}\text { Local ownership } \\
\text { of processing } \\
\text { and marketing }\end{array}$ & $\begin{array}{l}\text { Processing/ } \\
\text { market equip- } \\
\text { ment and } \\
\text { facilities growing }\end{array}$ & $\begin{array}{l}\text { Group recruits } \\
\text { new members }\end{array}$ & $\begin{array}{l}\text { Many different } \\
\text { markets main- } \\
\text { tained for } \\
\text { products }\end{array}$ & $\begin{array}{l}\text { Variety of } \\
\text { processing } \\
\text { methods used as } \\
\text { markets change }\end{array}$ & $\begin{array}{l}\text { Support refuges } \\
\text { and local } \\
\text { heritage } \\
\text { products }\end{array}$ & $\begin{array}{l}\text { New processing/ } \\
\text { marketing } \\
\text { systems and } \\
\text { products adopted }\end{array}$ \\
\hline $\begin{array}{l}\text { Farm and } \\
\text { farm family }\end{array}$ & $\begin{array}{l}\text { All systems on } \\
\text { farm are } \\
\text { independent but } \\
\text { connected }\end{array}$ & $\begin{array}{l}\text { Local managers } \\
\text { make land } \\
\text { decisions }\end{array}$ & $\begin{array}{l}\text { Farm assets, } \\
\text { equipment, } \\
\text { inventory }\end{array}$ & $\begin{array}{l}\text { Family and } \\
\text { friends ready to } \\
\text { help manage } \\
\text { farm }\end{array}$ & $\begin{array}{l}\text { Variety of sys- } \\
\text { tems (e.g., crop } \\
\text { and livestock) } \\
\text { integrated }\end{array}$ & $\begin{array}{l}\text { Farm uses old } \\
\text { and new tools to } \\
\text { produce heritage } \\
\text { and new products }\end{array}$ & $\begin{array}{l}\text { Wild refuges } \\
\text { maintained on } \\
\text { farm }\end{array}$ & $\begin{array}{l}\text { Kaizen (continu- } \\
\text { ous improvement) } \\
\text { of farm systems }\end{array}$ \\
\hline Soils & $\begin{array}{l}\text { Feedback tight } \\
\text { btw soil and soil } \\
\text { cover systems }\end{array}$ & $\begin{array}{l}\text { Soils need few } \\
\text { inputs to main- } \\
\text { tain productivity }\end{array}$ & $\begin{array}{l}\text { Soil health } \\
\text { increasing }\end{array}$ & $\begin{array}{l}\text { Soil systems, soil } \\
\text { cover reproduce } \\
\text { selves }\end{array}$ & $\begin{array}{l}\text { Diversity of soil } \\
\text { organisms, and } \\
\text { plants main- } \\
\text { tained }\end{array}$ & $\begin{array}{l}\text { Soil systems } \\
\text { adapt to changing } \\
\text { conditions }\end{array}$ & $\begin{array}{l}\text { Native flora, } \\
\text { fauna, EM } \\
\text { increasingly } \\
\text { relied on }\end{array}$ & $\begin{array}{l}\text { More systems for } \\
\uparrow \text { soil organic } \\
\text { matter and topsoil } \\
\text { depth }\end{array}$ \\
\hline Water & $\begin{array}{l}\text { Water resource } \\
\text { and need have } \\
\text { tight feedback }\end{array}$ & $\begin{array}{l}\text { Local water } \\
\text { harvest meets } \\
\text { local need }\end{array}$ & $\begin{array}{l}\text { Water capture } \\
\text { increasing }\end{array}$ & $\begin{array}{l}\text { Water sources } \\
\text { steady to } \\
\text { increasing }\end{array}$ & $\begin{array}{l}\text { Multiple water } \\
\text { sources available }\end{array}$ & $\begin{array}{l}\text { Variety of water } \\
\text { sources } \\
\text { developed/ } \\
\text { maintained }\end{array}$ & $\begin{array}{l}\text { Water systems } \\
\text { enhance } \\
\text { wilderness }\end{array}$ & $\begin{array}{l}\text { New systems em- } \\
\text { ployed to harvest } \\
\text { and store local } \\
\text { water }\end{array}$ \\
\hline Person & $\begin{array}{l}\text { Bonding and } \\
\text { bridging, social } \\
\text { capital }\end{array}$ & $\begin{array}{l}\text { Internal locus of } \\
\text { control }\end{array}$ & $\begin{array}{l}\text { Maintains equip- } \\
\text { ment, soil, water } \\
\text { catchment }\end{array}$ & $\begin{array}{l}\text { Heals quickly, } \\
\text { helps others } \\
\text { learn }\end{array}$ & $\begin{array}{l}\text { Has variety of } \\
\text { approaches, } \\
\text { attitudes }\end{array}$ & $\begin{array}{l}\text { Changes } \\
\text { approach when } \\
\text { need to }\end{array}$ & $\begin{array}{l}\text { Follows natural } \\
\text { cycles, eats } \\
\text { seasonal foods }\end{array}$ & $\begin{array}{l}\text { Regularly tries } \\
\text { new patterns, } \\
\text { breaks old habits }\end{array}$ \\
\hline
\end{tabular}

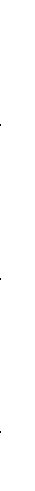

a RCDG=Rural Cooperative Development Grant program, VAPG=Value-Added Producer Grant program, FMPP=Farmers Market Promotion Program, LFPP=Local Food Promotion Program, F2S=Farm to School, NRCS=Natural Resource Conservation Service, BFRDP=Beginning Farmer/Rancher Development Program, MIG=Management Intensive Grazing 
validity of the eight qualities of resilient systems by integrating the nine case studies of resilient local food systems in recalcitrant areas of the Southern U.S. with previous frameworks or the qualities espoused by other frameworks.

We are attempting to create quantitative measures of each of the qualities and an overall sustainability/resilience index. In our approach, available data from every county in the 13 Southern states are united in an overall sustainability/ resilience index (SRI) that provides estimates of sustainability/resilience for each county in the South. These data are presented in draft form online (Worstell, 2016), along with practical tips for increasing resilience. We urge all other developers of resilience frameworks and models to consider quantification of their concepts to accompany their case study efforts. Such quantification can permit researchers to test whether their frameworks predict resilience. For example, Tsai, Wilson and Rahman (2015) used some of the data sources mentioned above to test resilience of rural counties to the 2007-2008 Great Recession. Their dependent variable, rebound in employment after the recession, was highly correlated with their resilience measures.

\section{Relating SRI to Social Demographic Variables}

As discussed above, ecological resilience avoids the polarizing aspects of other perspectives on sustainability with a measurable biological reality, the amount of disturbance a system can take before it dissolves without being able to reconstitute itself. The resilient system survives, the nonresilient does not. Ecological resilience assessment differs from sustainability assessment in one basic area: resilience assessments do not incorporate indicators unless they are associated with the ability of a system to withstand disturbance. An ultimate goal of resilience measurement is a set of indicators of the key qualities of ecological resilience across scales and types of systems, including soils and wildlife systems. Indicators of human social development are not available at the scale of soil or field.

Furthermore, if we are to determine whether sustainable and resilient local food systems contribute to broader goals of improving quality of life and wellbeing (Food, Agriculture, Conservation, and Trade Act 101-624, 16 U.S. C. \$1603, 1990; Toman, Lile, \& King, 1998; Exec. Order No. 13, 693, 2015), a crucial proposition of sustainable agriculture movements and policies, it is critical that our theoretical and analytical frameworks not confound them. Frameworks that incorporate all desired outcomes in measures of resilience cannot measure the contribution of the system to these desired outcomes. Because of this, we intentionally do not include traditional poverty or health indicators. It is not because they are not part of broader social resilience, but rather because we want to be able to measure the extent to which they are associated with the ecological indicators of system resilience.

Approached from the standpoint of ecological resilience, quantitative measures of sustainability/ resilience allow correlation of food system resilience with the variety of social indicators included in many traditional definitions of sustainability. Such analyses show the relationship of resilience to socially desirable characteristics that are only indirectly reflected in the fundamental qualities of resilience.

This approach enables examination of correlations of quantitative measures of resilience (such as our SRI) with measures of poverty, health, population, and other human social demographic variables. Determining the effect on such variables is crucial to determining whether ecologically resilient systems meet the quality of life or social criteria established by the various definitions of sustainability. We do have preliminary data (Green \& Worstell, in preparation) that show that indicators of poverty appear highly negatively correlated with our sustainability/resilience index. Others, such as health indicators, are highly positively correlated. One tentative conclusion of these studies being prepared for publication is that resilient systems, at least at the county level as measured by SRI, generally are accompanied by low poverty and high health outcomes. Some basic data is presented in draft form online at Worstell and Grand (2016).

Other social demographic variables such as education level or population trends, though not included in most definitions of sustainability, also have interesting relationships to SRI. Correlations of these various social demographic indicators with 
resilience are in preparation (Green \& Worstell, in preparation). We urge all other resilience analysts to consider the relationships of health, poverty, and other social-demographic variables as efforts to quantify resilience. If low levels of poverty and high levels of health outcomes are correlated with resilience, an ecological resilience approach to sustainability may achieve the societal objectives of sustainability while establishing roots in biological and ecological sciences.

\section{Conclusions}

Living systems survive and thrive when their integrated components work together to adapt and transform in response to similar adaptation and transformation of other complex adaptive systems. Those that survive and thrive are called ecologically resilient. Viewing sustainability from a resilience perspective offers a means of reducing polarization and solving wicked problems due to the simple and observable definition of resilience. Defining and measuring the qualities of resilient systems should facilitate design and enhancement of similar systems.

We have identified eight qualities consistently shown in our case studies of uniquely resilient food systems in conjunction with examination of six prominent frameworks of ecological resilience. Identifying these qualities of resilient food systems was our first step toward a quantitative index of sustainability and resilience. We are using the resulting sustainability/resilience index to assess and help entrepreneurs and other managers to improve resilience at the community and farm level. Our continuing mission is to refine the index and our toolbox and extend it to various scales. We seek a set of descriptive statements that apply to multiple levels. For example, below is a set of statements summarizing our findings with food systems, but expressed at the community level by substituting community for food system.

C: A resilient community is independent yet tightly connected to other communities, markets, and government policy systems.

L: A resilient community has many LSO processing and marketing enterprises.

A: A resilient community accumulates reserves and physical infrastructure that enable withstanding disturbance.

R: A resilient community establishes back-ups and redundancy.

D: A resilient community has a diversity of complementary enterprises.

I: A resilient community encourages regular innovation that conserves the tried and true qualities that built it.

E: A resilient community works with nature to minimize imported manufactured inputs, moving toward ecological integration.

$\mathrm{T}$ : A resilient community embraces disturbance and periodically transforms itself.

The acronym CLARDIET expresses the eight qualities consistently found in systems that last. The eight qualities can also be expressed in a conceptual model expressed as $\mathrm{SRI}=\mathrm{f}(\mathrm{C}, \mathrm{L}, \mathrm{A}, \mathrm{R}, \mathrm{D}$, I, E, T). Future research will define these qualities and their relationships to better explain, predict, and facilitate resilient sustainability.

Our framework lays a foundation for a virtually unlimited set of studies that will help increase resilience to climate change, economic change, technological change, political change, or any of a vast set of potential disturbances of our social agroecosystems.

\section{Acknowledgements}

The authors thank research assistants who participated in case study development: Leesa Johnson, Anna Nassiff, and Selina Straub.

\section{References}

Alinovi, L., D'Errico, M., Mane, E., \& Romano, D. (2010, June). Liveliboods strategies and household resilience to food insecurity: An empirical analysis to Kenya. Paper prepared for the conference Promoting Resilience through Social Protection in Sub-Saharan Africa, Dakar, Senegal. Retrieved from http://erd.eui.eu/ media/BackgroundPapers/Alinovi-RomanoD'Errico-Mane.pdf

Alinovi, L., Mane, E., \& Romano, D. (2009). Measuring household resilience to food insecurity: Application to Palestinian households (EC-Food and Agriculture 
Organization [FAO] Food Security Programme Working Paper). Rome: FAO. Retrieved from http://www.fsnnetwork.org/measuring-householdresilience-food-insecurity-application-palestinianhouseholds

Andrew, L., Arndt, D., Beristain, N., Cass, T., Clow, T., Colmenares. B. ... \& McCallum, M. L. (2016). Changes in United States' citizens' interest in sustainability (2004-2014). Life: The Excitement of Biology, 4(3), 138-164. http://dx.doi.org/10.9784/LEB4(3)

Binder, C. R., Hinkel, J., Bots, P., \& Pahl-Wostl, C. (2013). Comparison of frameworks for analyzing social-ecological systems. Ecology and Society, 18(4), Article 26. http://dx.doi.org/10.5751/ES-05551180426

Cabell, J. F., \& Oelofse, M. (2012). An indicator framework for assessing agroecosystem resilience. Ecology and Society, 17(1), 18. Retrieved from http://www.ecologyandsociety.org/vol17/iss1/ art18/

Camazine, S., Deneubourg, J.-L., Franks, N. R., Sneyd, J., Theraulaz, G., \& Bonabeau, E. (2003). Selforganization in biological systems. Princeton, New Jersey: Princeton University Press.

Carpenter, S. R., Arrow, K. J., Barrett, S., Biggs, R., Brock, W. A., Crépin, A.-S. ... \& de Zeeuw, A. D. (2012). General resilience to cope with extreme events. Sustainability, 4(12), 3248-3259. http://dx.doi.org/10.3390/su4123248

Cerf, M., Jeuffroy, M., Prost, L., \& Meynard, J. (2012). Participatory design of agricultural decision support tools: Taking account of the use situations. Agronomy for Sustainable Development, 32(4), 899-910. http://dx.doi.org/10.1007/s13593-012-0091

Ciani, F., \& Romano, D. (2013). Testing for housebold resilience to food insecurity: Evidence from Nicaragua. Florence, Italy: Department of Economics and Management, University of Florence. Retrieved from http://www.siecon.org/online/wpcontent/uploads/2013/09/Ciani-Romano.pdf

Crossfield, P. (2009). Global Harvest Initiative seeks not to feed people, but to bolster big agriculture's profits [Blog post]. Huffington Post. Retrieved from http://www.huffingtonpost.com/paulacrossfield/global-harvest-initiative b 294482.html
Curry, J. (2013, May 29). Forget sustainability-it's about resilience. [Blog post]. Retrieved from https://judithcurry.com/2013/05/29/forgetsustainability-its-about-resilience/

Exec. Order No. 13, 693, 3 C. F. R. 281-296. (2015). Planning for federal sustainability in the next decade. Washington, D.C.: Government Printing Office. Retrieved from https://www.whitehouse.gov/thepress-office/2015/03/19/executive-orderplanning-federal-sustainability-next-decade

Flora, C. B., Flora, J. L., \& Gasteyer, S. P. (2015). Rural communities: Legacy and change (5th ed.). Boulder, Colorado: Westview Press.

Food, Agriculture, Conservation, and Trade Act 101624, 16 U.S. C. \1603, Definitions. (Government Printing Office, 1990). Retrieved from https://www.agriculture.senate.gov/download/co mpilation/101-624-food-agriculture-conservationand-trade-act-of-1990

Food and Agriculture Organization of the UN [FAO]. (2014). Resilience index: Measurement and analysis model. Rome: Author. Retrieved from http://www.fao.org/3/a-i4102e.pdf

Forrester, J.W. (1971). Counterintuitive behavior of social systems. Theory and Decision, 2(2), 109-140. Retrieved from http://constitution.org/ps/cbss.pdf

Frankenberger, T., Mueller, M., Spangler, T., \& Alexander, S. (2013). Community resilience: Conceptual framework and measurement Feed the Future learning agenda. Rockville, Maryland: Westat. Retrieved from https://agrilinks.org/sites/default/files/resource/ files/FTF\%20Learning Agenda Community Resilience_Oct $\% 202013 . p d f$

Frick, K. T., Weinzimmer, D., \& P. Waddell, P. (2014). The politics of sustainable development opposition: State legislative efforts to stop the United Nation's Agenda 21 in the United States. Urban Studies, 52(2), 209-232. http://dx.doi.org/10.1177/0042098014528397

Grenz, J. (2011). RISE (Response-Inducing Sustainability Evaluation), version 2.0. Field Manual. Zollikofen, Switzerland: Swiss College of Agriculture. Retrieved from http://www.saiplatform.org/uploads/Mod ules/Library/What $\% 20$ is $\% 20$ RISE $\% 202$.pdf 
Hahn, M. B., Riederer, A. M., \& Foster, S. O. (2009). The livelihood vulnerability index: A pragmatic approach to assessing risks from climate variability and change. A case study in Mozambique. Global Environmental Change, 19(1), 74-88. http://dx.doi.org/10.1016/j.gloenvcha.2008.11.002

Holling, C. S. (1973). Resilience and stability of ecological systems. Annual Review of Ecology and Systematics, 4(1), 1-23. Retrieved from http://dx. doi.org/10.1146/annurev.es.04.110173.000245

Holling, C. S. (1996). Engineering resilience versus ecological resilience. In P. Schulze (Ed.), Engineering within ecological constraints (pp. 31-44). Washington, D.C.: National Academy Press.

Holt-Giménez, E., \& Altieri, M. (2016). Agroecology "lite": Cooptation and resistance in the global North. Oakland, California: Food First. Retrieved from https://foodfirst.org/agroecology-lite-cooptationand-resistance-in-the-global-north/

Hughes, K., \& Bushell, H. (2013). A multidimensional approach for measuring resilience. Oxford, UK: Oxfam GB. Retrieved from http://policy-practice.oxfam. org.uk/publications/a-multidimensional-approachto-measuring-resilience-302641

Lauckner, H., Paterson, M., \& Krupa, T. (2012). Using constructivist case study methodology to understand community development processes. The Qualitative Report, 17(13), 1-22. Retrieved from http://nsuworks.nova.edu/cgi/viewcontent.cgi? $\underline{\text { article }}=1790 \&$ context $=$ tqr

Levin, S. A. (1998). Ecosystems and the biosphere and complex adaptive systems. Ecosystems, 1(5), 431436. http://dx.doi.org/10.1007/s100219900037

Levine, S. (2014). Assessing resilience: Why quantification misses the point. London: Overseas Development Institute. Retrieved from http://capacity4dev.ec. europa.eu/resilience ethiopia/document/assessingresilience-why-quantification-misses-point-simonlevine-2014-humanitarian-policy-

Low, S. A., Adalja, A., Beaulieu, E., Key, N., Martinez, S., Melton, A. ... \& Jablonski, B. B. R. (2015). Trends in U.S. local and regional food systems (AP-068). Washington, D.C.: U.S. Department of Agriculture, Economic Research Service. Retrieved from https://www.ers.usda.gov/publications/pubdetails/?pubid $=42807$
Lowdermilk, W. C. (1948). Conquest of the land through seven thousand years. Washington, D.C.: U.S. Department of Agriculture, Soil Conservation Service.

Martinez, S., Hand, M., Da Pra, M., Pollack, S., Ralston, K., Smith, T. ... \& Newman, C. (2010). Local foods systems: Concepts, impacts, and issues (ERR-97).

Washington, D.C.: U.S. Department of Agriculture, Economic Research Service. Retrieved from https://www.ers.usda.gov/publications/pubdetails $/$ ?pubid $=46395$

May, R. M. (2002). The future of biological diversity in a crowded world. Current Science, 82(11), 1325-1331. Retrieved from http://www.iisc.ernet.in/currsci/ jun102002/1325.pdf

Moore, O., McCarthy, O., Byrne, N., \& Ward, M. (2014). Reflexive resilience and community supported agriculture: The case that emerged from a place. Journal of Agriculture, Food Systems, and Community Development, 4(3), 137-153. http://dx.doi.org/10.5304/jafscd.2014.043.007

Paulson, J., (2010, July). Sustainability is a wicked problem. St. Paul: University of Minnesota Dairy Extension. Retrieved from http://www.extension. umn.edu/agriculture/dairy/farm-life/sustainabilityis-a-wicked-problem/

Raskin, P. (2014). A great transition? Where we stand. Keynote address at the biennial conference of the International Society for Ecological Economics, Reykjavik, Iceland. Retrieved from http://www.greattransition.org/publication/agreat-transition-where-we-stand

Rittel, H. W., \& Webber, M. M. (1973). Dilemmas in a general theory of planning. Policy Sciences, 4(2), 155 169. http://dx.doi.org/10.1007/BF01405730

Rockefeller Foundation, The. (2014). City resilience framework. New York: Author. Retrieved from https://www.rockefellerfoundation.org/report/city -resilience-framework/

Scoones, I. (1998). Sustainable rural livelihoods: A framework for analysis (Institute for Development Studies [IDS] Working Paper 72). Brighton, UK: IDS. Retrieved from http://www.ids.ac.uk/publication/sustainable -rural-livelihoods-a-framework-for-analysis 
Stockholm Resilience Center. (2015). Applying resilience thinking. Seven principles for building resilience in socialecological systems. Stockholm: University of Stockholm. Retrieved from http://www.stockholm resilience.org/download/18.10119fc11455d3c557d 6928/1459560241272/SRC+Applying+Resilience+ final.pdf

Stokols, D., Lejano, R. P., \& Hipp, J. (2013). Enhancing the resilience of human-environment systems: A social ecological perspective. Ecology and Society, 18(1), 7. Retrieved from http://www.ecologyand society.org/vol18/iss1/art7/

Strolling of the Heifers. (2016). 2016 Locavore Index: Which states are most committed to locally-sourced food? Brattleboro, Vermont: Author. Retrieved from http://www.strollingoftheheifers.com/locavore index/

Sustainable Agriculture Initiative Platform. (2016). Who we are. Brussels: SAI Platform. Retrieved from http://www.saiplatform.org/about-us/who-we-are

Toman, M. A., Lile, R., \& King, D. (1998). Assessing sustainability: Some conceptual and empirical challenges. Washington, D.C.: Resources for the Future. Retrieved from http://ageconsearch.umn.edu/ handle/10756

Total Materia. (2001). Resilience. Zurich, Switzerland: Author. Retrieved from http://www.totalmateria.

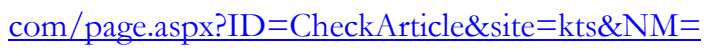
41

Tsai, C-Y., Wilson, P., \& Rahman, T. (2015). Economic resilience and vulnerability in the rural $W$ est (Departmental Working Paper 2015-01). Tucson, Arizona: Department of Agricultural and Resource Economics, University of Arizona. Retrieved from http://purl.umn.edu/202969

U.S. Climate Change Science Program [U.S. CCSP]. (2008). Our changing planet: The U.S. climate change science program for fiscal year 2009. Washington, D.C.: Author. Retrieved from http://www.globalchange. gov/browse/reports/our-changing-planet-usclimate-change-science-program-fiscal-year-2009

U.S. Department of Agriculture. (2001). Food and agricultural policy: Taking stock for the new century (pp. 16-35) [Technical report]. Washington, D.C.: USDA. Retrieved from https://catalog.hathitrust.org/Record/003573898
Van Meensel, J., Lauwers, L., Kempen, I., Dessein, J., \& Van Huylenbroeck, G. (2012). Effect of a participatory approach on the successful development of agricultural decision support systems: The case Pigs2win. Decision Support Systems, 54(1), 164-172. http://dx.doi.org/10.1016/j.dss.2012.05.002

Van Passel, S., \& Meul, M. (2012). Multilevel and multiuser sustainability assessment of farming systems. Environmental Impact Assessment Review, 32(1), 170180. http://dx.doi.org/10.1016/j.eiar.2011.08.005

Vermeulen S. J., Campbell, B. M., \& Ingram, J. S. I. (2012). Climate change and food systems. Annual Review of Environment and Resources, 37(1), 195-222. http://dx.doi.org/10.1146/annurev-environ020411-130608

Walker, B., \& Salt, D. (2006). Resilience thinking: Sustaining ecosystems and people in a changing world. Washington, D.C.: Island Press.

Weber, C. L., \& Matthews, H. S. (2008). Food-miles and the relative climate impacts of food choices in the United States. Environmental Science \& Technology, 42(10), 3508-3513. http://dx.doi.org/10.1021/es702969f

Wenninger, D. (2013). Sustainable agriculture and local sourcing at Walmart. Arlington, Virginia: Agricultural Outlook Forum. Retrieved from https://www.usda.gov/oce/forum/presentations/ Wenninger.pdf

Wezel, A., Bellon, S., Dore, T., Francis, C., Vallod, D., \& David, C. (2009). Agroecology as a science, a movement and a practice. A review. Agronomy for Sustainable Development, 29(4), 503-515. http://dx.doi.org/10.1051/agro/2009004

World Bank. (2014). A wicked problem: Controlling global climate change. Washington, D.C.: The World Bank. Retrieved from http://www.worldbank.org/en/ news/feature/2014/09/30/a-wicked-problemcontrolling-global-climate-change

World Commission on Environment and Development. (1987). Report of the world commission on environment and development: Our common future. New York: United Nations. Retrieved from http://www.undocuments.net/our-common-future.pdf

Worstell, J. V. (1995). Southern futures: Opportunities for sustainable agricultural systems (State of the South Report). Retrieved from http://mysare.sare.org/ wp-content/uploads/483Southern $\% 20$ Futures.pdf 
Worstell, J. V. (2016). Sources of resilience. Fox, Arkansas:

The Resilience Project. Retrieved from https://meadowcreekvalley.wordpress.com/ projects/

Worstell, J. V., \& Grand, K. (2016). Sustainability, resilience and quality of life. Fox, Arkansas: The Resilience Project. Retrieved from https://meadowcreekvalley.files.wordpress.com/ 2015/05/srs-chapter-13-quality-of-life.pdf

Worstell, J. V., \& Johnson, L. (2015). Relating sustainability, resilience, permaculture, agroecology, organic agriculture, and vulnerability. Fox, Arkansas: The
Resilience Project. Retrieved from https://meadowcreekvalley.files.wordpress.com/ 2015/05/srs-chapter-11-permaculture-sus-vulneraorg.pdf

Worstell, J. V., \& Johnson, L. (2016). Working with nature: Towards ecological integration. Fox, Arkansas: The Resilience Project. Retrieved from https://meadowcreekvalley.files.wordpress.com/ 2015/05/srs-chapter-4-ei.pdf

Yin, R. K. (2014). Case study research: Design and methods. Los Angeles: SAGE. 